Netherlands and foreigners, alike". In fact, they remain a small-scale experiment mainly in one city, Maasbommel. Scaling them up to floating communities has proved difficult owing to a lack of regulations and good business models, problems not discussed in the book.

The most regrettable dearth of analysis is in the chapter on carbon markets. The authors argue that the market will work wonders, if we let it. They acknowledge that some carbon-offset schemes are scams and that the European Union's Emission Trading System (EU ETS) had problems at the beginning, then quickly go on to call for carbon markets to be rolled out widely. There is no alternative, Lovins and Cohen say, because a carbon tax is not appealing to US politicians.

Not so. Economic studies suggest that a carbon tax may be more costefficient than a cap-and-trade system (B. B. F. Wittneben Energy Policy 37, 2462-2464; 2009). It provides a clear price signal, requires less bureaucracy, which reduces costs, and accrues revenue straight to the government that collects it. Most importantly with such an approach, there is no upper limit on emissions reduction. So why rule out a carbon tax as one of the tools of climate capitalism? Carbon taxes have indeed been successful elsewhere, for example, in British Columbia, Canada.

Nor are the market-based solutions as great as Climate Capitalism makes out. As a result of intense lobbying, some big polluters, particularly in the utilities sector, made windfall profits from the EU ETS without reducing emissions. Carbonmarket fraud is also on the rise. One estimate suggests that such crime has cost the EU at least $€ 5$ billion (US $\$ 7.3$ billion) since 2007 (M. K. Dorsey and J. Whitington Carbon Market Europe 9, 7; 2010). In January, the Commission suspended EU ETS transactions for a week after a series of frauds.

Naked greed is not a motivating force for sustainability; it is a disruptive one. Although the positive examples that Lovins and Cohen present are inspiring, they are not enough. Binding international agreements and new governance mechanisms that address our integrated environmental issues - including, but not restricted to, emissions cuts - will compel businesses to engage more deeply with science.

Gail Whiteman is a professor in the Department of Business Society Management, Rotterdam School of Management, Erasmus University, Rotterdam, the Netherlands. e-mail:gwhiteman@rsm.nl

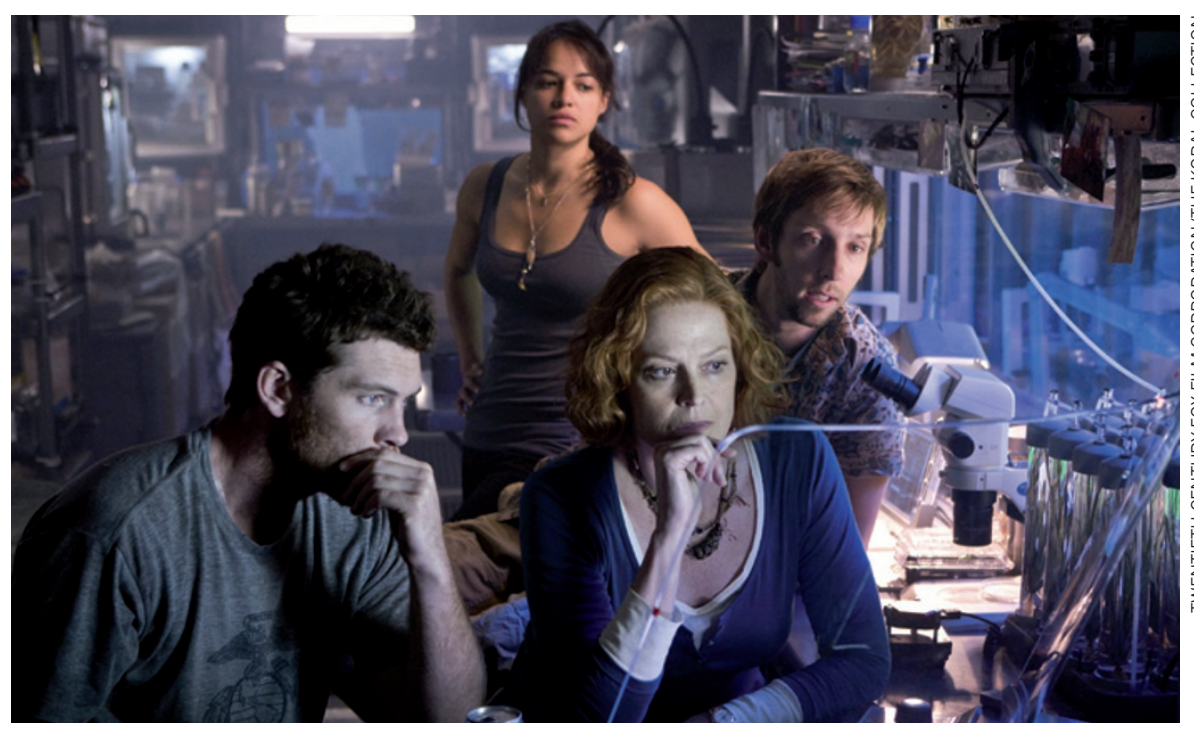

Sigourney Weaver (front right) in Avatar: director James Cameron sought scientific advice over her lines.

\title{
COMMUNICATION
}

\section{Popcorn and Petri dishes}

\section{Cinemas are today's scientific lecture halls, finds Kevin Hand in a book probing how research enriches film.}

I $n$ the autumn of 2007 I was at the American Geophysical Union conference in San Francisco, California, when my mobile phone rang. The number was blocked; as a recently minted $\mathrm{PhD}$ with credit-card debt, I assumed it was a company trying to track me down. Nevertheless, I answered.

To my surprise, the voice at the other end asked, "Dr Hand? I’ve got James Cameron on the line from New Zealand. Do you have a few minutes to help him?"I had worked with the director before and knew he was working on his next film. Cameron got on the line and described to me life on his distant planet. He needed to feed Sigourney Weaver a few lines of science jargon. Within $20 \mathrm{~min}$ utes we had it figured out. I put my mobile away and went on with the meeting.

Later that week I would give my talk about Jupiter's moon Europa to some 200 attendees. Two years later, Cameron's film Avatar reached many tens of millions of viewers.

Granted, should we some day discover life on Europa, it will dwarf the impact of any Hollywood movie. But we won't get a chance to search for that life unless the tax-paying millions that watch films care enough about our potential discoveries to invest their dollars in them. From supercolliders to NASA missions, big science is going extinct, in part because politicians and public are missing the relevance; the story isn't there. Science stands to benefit from a symbiotic relationship with those who know how to tell stories, notably film-makers.
In Lab Coats in Hollywood, scholar of science communication David Kirby analyses the interplay between science consultants and Hollywood film-makers. His approach is academic, but numerous examples and interesting historical details make for an enjoyable read. The book is in part a handbook for those who might try to influ-

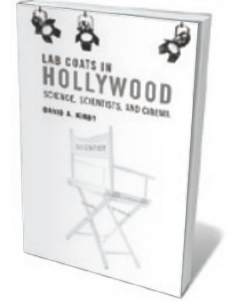

Lab Coats in Hollywood: Science, Scientists, and Cinema DAVID A. KIRBY MIT Press: 2011. 264 pp. $\$ 27.95$ ence the way in which science and technology are portrayed on the big screen.

Kirby notes that science advisers often labour under the misconception that there is a tension between accuracy and entertainment in film-making. On the contrary: for film-makers, he says, "there is only entertainment". The best approach for a scientist is thus to focus on how accurate science can make the story better. Rare directors such as Stanley Kubrick and Cameron are obsessed with scientific integrity, but the majority of them use it as ornament.

Although some of Kirby's conclusions are obvious, I found two concepts particularly intriguing. He argues that films are a powerful "virtual witnessing technology", in that they provide the mechanism for people to gain 
access to evidence for scientific knowledge. He borrows from the late US evolutionary biologist Stephen Jay Gould, who argued that the "need for direct witnessing is what separates scientific practice from religious faith".

So films serve as the descendant of the theatrical public science lecture, such as those implemented in the nineteenth century by Britain's Royal Institution, in which luminaries like Michael Faraday demonstrated experiments to a live audience. The public could verify the outcomes with their own eyes. Cinema can have a similar effect, even when the viewer is witnessing a simulated experiment on the screen.

Kirby also explores the concept of the "diegetic prototype" - inventions demonstrated in the fictional world that catalyse developments in the real world. For example, the imagined prototypes for rockets and lunar exploration presented in Fritz Lang's 1929 film Woman in the Moon and the 1950 film Destination Moon, whose technical adviser was science-fiction writer Robert A. Heinlein, helped to lay the foundation for the political, public and scientific acceptance needed to move space endeavours forward.

Yet, as most researchers are aware, science regularly suffers at the hands of a good story. From the extremes of weather to vaccines and autism, anecdote frequently trumps data. The response of the scientific community is often to seek new and better data. But on the landscape of knowledge, what society needs is not a better map, but a better description of how to navigate the terrain. Science is best conveyed to the public in a compelling narrative.

Love it or hate it, Hollywood remains influential. We may, as scientists, be disappointed that society prefers character over content. As Carl Sagan remarked in his 1996 book, The Demon-Haunted World: "if, for whatever reason, people dislike the stereotypical scientist, they are less likely to support science". But a good on-screen portrayal of science and scientists allows us to incorporate valuable facts and ideas into entertaining stories. And as Kirby details, new mechanisms for collaboration are emerging. Over the past three years, the National Academy of Sciences' Science and Entertainment Exchange (go.nature.com/ pcxgsm) has connected film-makers with scientists to brainstorm about how to use good science to build a better story.

Lab Coats in Hollywood provides a framework for scientists to better understand how to influence good storytelling with accurate information. We don't all wear lab coats, but a few more beakers behind the scenes could go a long way towards enhancing critical thinking in modern society.

Kevin Hand is a planetary scientist at the Jet Propulsion Laboratory, California Institute of Technology, Pasadena, California, USA. e-mail:kevin.p.hand@jpl.nasa.gov

\section{Books in brief}

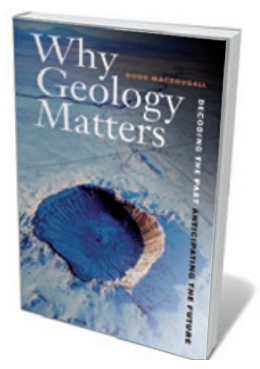

Why Geology Matters: Decoding the Past, Anticipating the Future Doug Macdougall UNIVERSITY OF CALIFORNIA PRESS 304 pp. $\$ 29.95$ (2011)

From mountain ranges to meteorite craters, the story of our planet is embedded in its rocks. In a wide-ranging and entertaining overview of the field, geologist Doug Macdougall explains how Earth scientists have unravelled the secrets of geological time, plate tectonics, volcanoes, earthquakes, past climates and the fossil record. He also muses on the role of geology in addressing pressing problems such as climate change and the continued provision of energy.

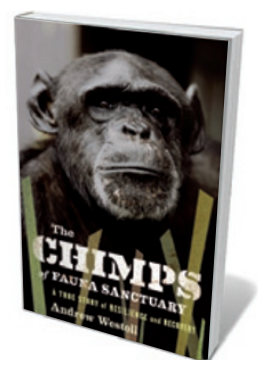

\section{The Chimps of Fauna Sanctuary: A True Story of Resilience and Recovery}

Andrew Westoll HOUghton MiffLIN HARCOURT 288 pp. \$25 (2011)

Biologist-turned-writer Andrew Westoll relates his experience as a volunteer at Gloria Grow's chimpanzee sanctuary near Montreal in Canada. In a vivid narrative, he describes how he got to know the rescued chimps. Many of them had come from a biomedical facility or were kept as pets, and some showed psychological problems as a result. He tells how the more time he spent with the animals, the more he learned about their behaviour and the stresses they endured in their captive lives.

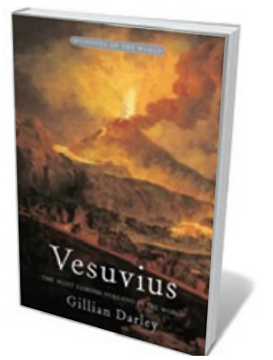

Vesuvius: The Most Famous Volcano in The World Gillian Darley PROFILE BOOKS 224 pp. £15.99 (2011)

Looming over the bay of Naples, Vesuvius is the only active volcano on the European mainland. It has mesmerized locals and visitors alike for two millennia with its majestic beauty, geological treasure trove and vicious eruptions - although none has since matched the devastation of the explosion that destroyed Pompeii in AD 79. In an elegant exploration of the volcano's allure, author Gillian Darley recounts how Vesuvius has inspired literature, imagery and science, from the first serious studies of volcanic activity during the Enlightenment to paintings by Andy Warhol.

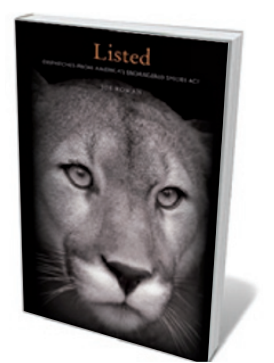

Listed: Dispatches from America's Endangered Species Act Joe Roman HARVARD UNIVERSITY PRESS 368 pp. \$27.95 (2011) In his tour of the places where rare species have stood in the way of dams and developments across the United States, ecologist and writer Joe Roman analyses the impact of the 1973 US Endangered Species Act. Using examples such as the whooping crane, North Atlantic right whale and the purple bankclimber - a freshwater mussel enmeshed in a water war with the city of Atlanta, Georgia - he argues that protecting biodiversity benefits economies and well-being alike, showing that species extinctions have a tangible impact on humans.

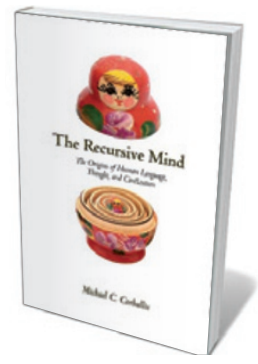

The Recursive Mind: The Origins of Human Language, Thought, and Civilization

Michael C. Corballis PRINCETON UnIVERSITY PRESS 288 pp. \$29.95 (2011)

What makes us human? Psychologist Michael Corballis argues that it is our ability to embed thoughts in other thoughts - known as recursion - rather than language that allows us to conceive of ourselves and others, and to witness the passing of time. He suggests that recursive minds were crucial to the survival of our Pleistocene ancestors and led to the emergence of societies, toolmaking and culture as well as communication. 